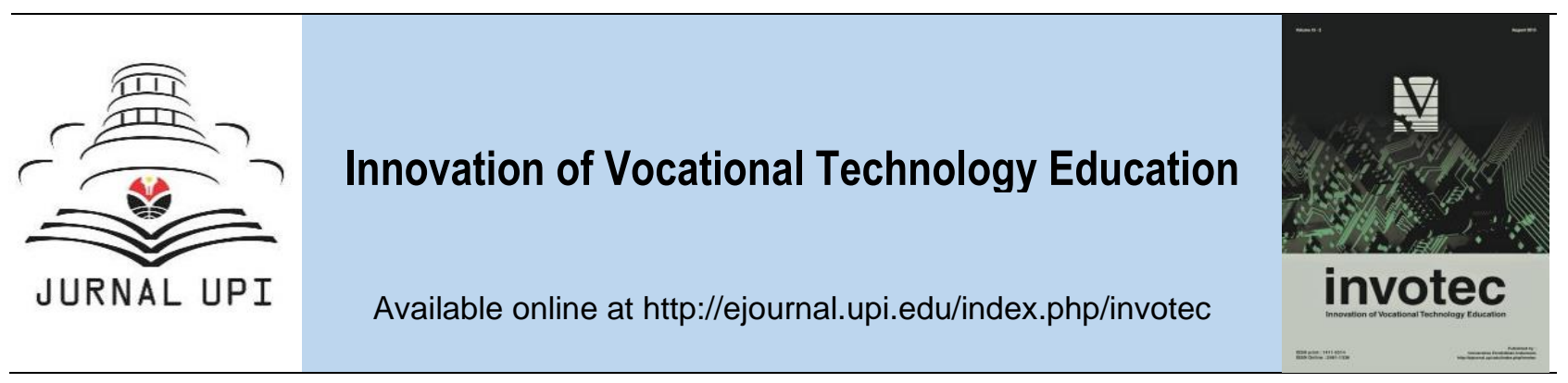

\title{
Flipping the Technical and Vocational Classroom for Increased Instructional Outcomes
}

\author{
Jonah Mupita ${ }^{1}$, Ade Gafar Abdullah', and Frank Bünning ${ }^{2}$ \\ ${ }^{1}$ Universitas Pendidikan Indonesia, Bandung, Indonesia \\ ${ }^{2}$ Otto-von-Guericke-Universität Magdeburg, Magdeburg, Germany
}

\section{ARTICLE INFO}

\section{Article history:}

Received: 07 October 2019

Received in revised form: 10 December 2019

Accepted: 20 January 2020

Available online: 29 February 2020

Keywords:

flipped classroom, traditional classroom, active learning, self-directed learning, learning outcomes

Authors email: tinayelong97@upi.edu ade_gaffar@upi.edu

\section{A B S T R A C T}

\begin{abstract}
Higher learning institutions are under immense pressure to evolve within the realms of the fourth industrial revolution. Training institutions are anticipated to minimize learning costs in the face of increasing enrolments. The flipped classroom model is a suitable instructional pedagogy to achieve institutional goals considering the current ubiquitousness of information and communication technology. The systematic review was aimed at summarizing and identifying research gaps that help inform future research trajectories. The 3-step review process was composed of articles searching and retrieval, filtering and sorting, and final inclusion. Identified empirical articles were; i.) Retrieved and summarized on the basis of tittles, abstracts, methods and basic findings, ii.) Filtered and sorted on the basis of study discipline, and iii.) Synthesized on the basis of basic findings. It was found that the flipped classroom improved academic performance to a limited extent. Most articles unanimously concurred that the flipped classroom model makes learning enjoyable and enables the development of lower order cognitive skills outside class and higher order cognitive skills through F2F (face to face) active learning. The success of the model in higher education is hinged on excellent planning, implementation and evaluation.
\end{abstract}

\section{Introduction}

Flipped classroom instructional model was pioneered by Jonathan Bergmann and Aaron Sams in 2007 (Bergmann \& Sams, 2012). The model was initially developed as a means to save time and ensure that absent students catch up after accessing prerecorded instructional materials. The flipped/ inverted classroom concept is also partially credited to Salman Khan who founded the Khan Academy, a free online system that covers multitudes of topics and subjects (Roach, 2014). The convectional teacher-centered methods of learning are fast being substituted because of some limitations among them the promotion of rote memorization at the expense of attaining higher order cognitive skills (Kurbanoĝlu \& Akkoyunlu, 2016). The obsoleteness of the convectional lecture transmissive model is paving way for the flipped classroom model packaged with active in-class 
tasks and pre-/post-class work (Abeysekera \& Dawson, 2015). Flipped classroom switches the activities traditionally done in class with those used to be completed outside class (Baytiyeh \& Naja, 2017; Becker \& Birdi, 2018; Blau \& Shamir-Inbal, 2017; Calimeris \& Sauer, 2015; Engel, Heinz, \& Sonntag, 2017; Hao, 2016; Kim et al., 2014; Kong \& Song, 2015; Lee \& Lai, 2017; Murphy, Chang, \& Suaray, 2016; Olitsky \& Cosgrove, 2016; Ravishankar, Epps, \& Ambikairajah, 2018; Şengel, 2016; Sohrabi \& Iraj, 2016; Yilmaz, 2017). In this instructional pedagogy, the teacher acts as a guide or facilitator (Lopes \& Soares, 2018). Flipped classroom is sometimes known as the inverted classroom or peer instruction. In a flipped classroom, subject materials are learnt in the form of videos, podcasts, online tutorials, voice over PowerPoint slides or audiovisuals in advance of class attendance (Gulley \& Jackson, 2016). The class time is reserved for active learning which enables learners to attain higher-order cognitive skills of the Bloom's taxonomy. In a flipped learning set up, videos, audiovisuals or podcasts are issued in advance of class attendance (Lee \& Lai, 2017). Content is usually accessed outside the classroom through various e-platforms.

A flipped classroom frees up more time for active learning through the use of games (team based learning), experiments, polling software and multimedia resources (Becker \& Birdi, 2018). Video technology is appealing to learners especially outside the classroom. The flipped classroom model supports diversity in students' learning pace, it is time effective, provides point-of-need assistance, provides more active learning opportunities for students, promotes development of higher-order cognitive skills, promotes better student-instructor (one-on-one) interaction, increases student responsibility for learning, addresses multiple learning styles, provides improvement on lecture material, promotes better student engagement and confidence through student-centered learning and collaboration, and provides easy access to the lesson content (Kurbanoĝlu \& Akkoyunlu, 2016). Past flipped classroom studies showed that flipped students performs better, are motivated and more satisfied than traditional classroom students (Lee \& Lai, 2017; Olitsky \& Cosgrove, 2016).

However, the substitution of content delivery mechanism, that is, from traditional lecture-based model to the flipped classroom model might come with adverse learning outcomes if not properly designed and implemented (Kurbanoĝlu \& Akkoyunlu, 2016). If students do not view the videos before attending class, active learning might not be enjoyable and lively (Lee \& Lai, 2017). Flipped classroom pedagogy add more responsibilities to instructors in terms of making the videos, online quizzes, assignments and other instructional materials (Baytiyeh \& Naja, 2017). Students used to having the conventional lecture method may also resist flipped classroom model and might face challenges in acquiring e-devices compatible with high speed internet (Kurbanoĝlu \& Akkoyunlu, 2016).

The broad aim of this systematic review was to establish the best evidence on how flipped instructional pedagogy has been applied in TVET-related higher education study disciplines. This article intends to help educators to understand why the adoption of a flipped classroom is inevitable during the current fourth industrial revolution. Educators might also appreciate why learners perceive 
the flipped classroom model as the instructional model of the moment as advocated by so many authors. The article also seeks to explore the gaps left by flipped classroom studies in measuring its impact on student achievement. Most articles on flipped classroom model dwelt much on the importance of the model on the basis of students' perceptions and little has been raised on how the flipped classroom improve student achievement. The review is also intended to provide a summary and a critique of various flipped classroom research topics and methods. The data could be used to identify important issues and questions in the literature and help to shape future research trajectories of the flipped classroom model.

The rest of the article will focus on the following; a critique of the flipped classroom model (background of flipped classroom), methods, results and discussion as well as the conclusion.

\section{Context and Review of Literature}

\subsection{Student-centered learning}

In the last decade, there has been a transition from teacher-centered pedagogies and practices to student-centered learning approaches. Latest instructional approaches put students' needs, interests, backgrounds and preferred learning styles ahead of the interests of education practitioners (Kurbanoĝlu \& Akkoyunlu, 2016). Researches have shown that, in order to maximize educational outcomes, learning and teaching should be supported by the now ubiquitous information technology (Ferreri \& O'Connor, 2013). Higher education has realized that technology supported pedagogies are indispensable in order to enhance active learning, keep students engaged, satisfy students' needs and wants (Sohrabi \& Iraj, 2016). That realization gave birth to the integration of face to face and online learning (blended learning and flipped classroom models) (Roehl, Reddy, \& Shannon, 2013).

\subsection{Flipped classroom model}

The flipped classroom was first adopted at higher education level following the K-12 practices (Albert \& Beatty, 2014). In higher education, it is mostly applied at postgraduate level and popular online resources bank at the disposal of instructors like Khan Academy, Coursera, and TED talks were developed to promote it (Arnold-Garza, 2014). The flipped classroom is both a skills development and content transmission instructional pedagogy.

The flipped classroom differs with the traditional lecture-based model in that learners are first exposed to learning materials outside class. Students learn the materials in the form of videos, simulations, podcasts, PowerPoint slides to mention a few technology-aided learning materials (Kurbanoĝlu \& Akkoyunlu, 2016). In the class, the students apply, synthesize, analyze and evaluate what they would have studied outside class (Olitsky \& Cosgrove, 2016). In the classroom the instructor's role will be limited to guidance and the student drives real learning. 


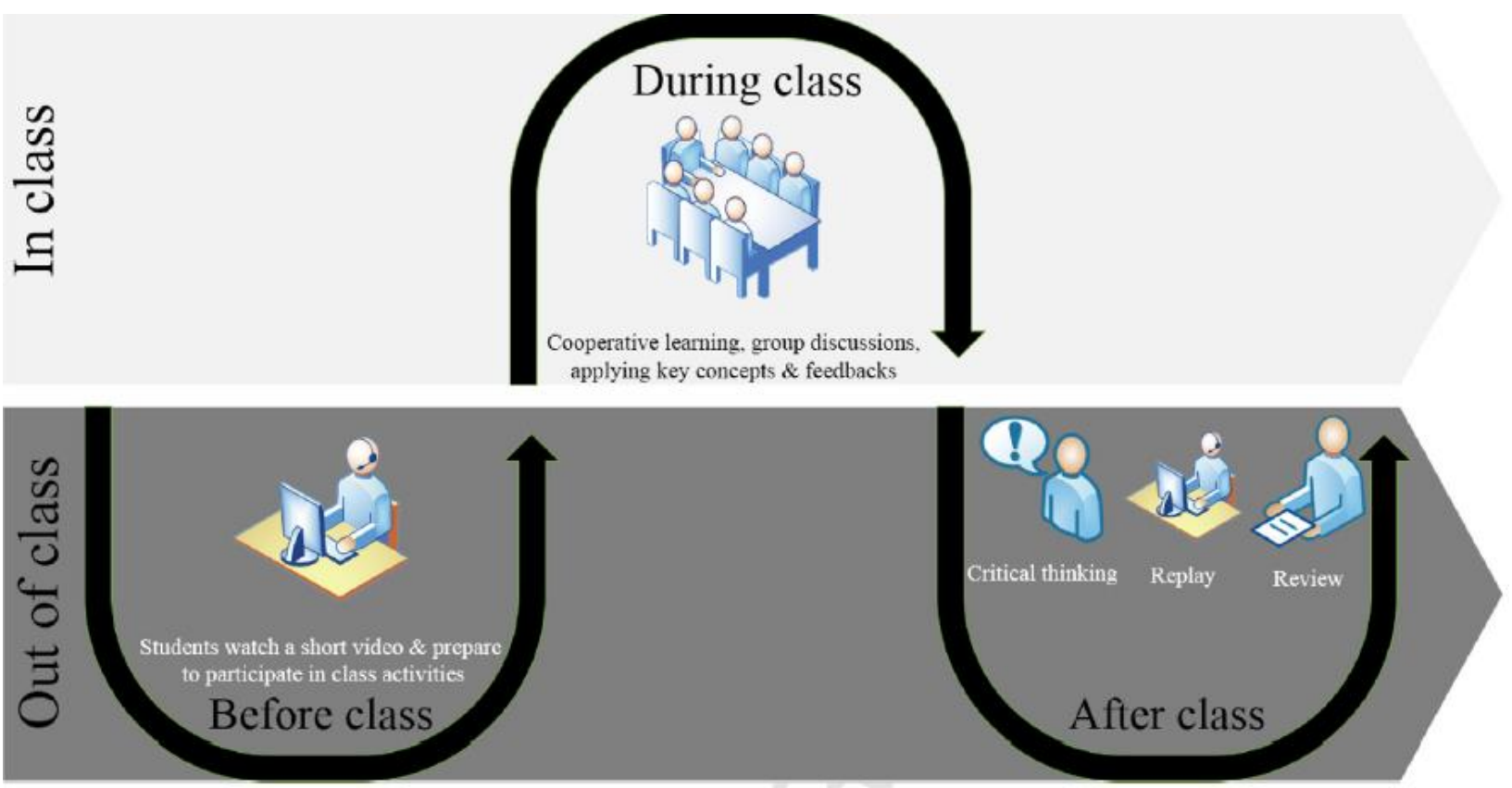

Figure 1. Flipped learning cycle (Adopted from Munir et al., 2018)

The purpose of flipping is to ensure that students are engaged in active learning through which they will apply concepts acquired through heutagogy (self-directed learning). In a flipped class, videos are recorded and forwarded to students for watching ahead of class (Kurbanoĝlu \& Akkoyunlu, 2016).

In a study about flipped classroom, flipped learning was found to increase grades in the medium-term over the traditional learning $(76.6 \%$ vs $72.8 \%)$. In this study with 3 tests, two out of three revealed that flipped students significantly scored better than students taught face to face, test $1 ; \mathrm{t}(527,295)=-2.666, \mathrm{p}<0.008$ and test $3 ; \mathrm{t}(558,305)=-2.605, \mathrm{p}<0.009$ (Albert \& Beatty, 2014).

Most studies revealed convincing evidence of a flipped pedagogy with regards to the affective dimension (Rivera, 2015). Most students reported positively about it (Abeysekera \& Dawson, 2015; AlJarrah, Thomas, \& Shehab, 2018; Eryilmaz \& Cigdemoglu, 2018; Foster \& Stagl, 2018). 78\% of the tertiary students in a research conducted in Malaysia reported that video watched were clear and easy to understand (Wang, 2017). The collaborative class sessions are usually time effective because students will be ceased with learning by doing through group and peer instruction (Guerrero et al., 2015; O'Flaherty \& Phillips, 2015). However instructor and student commitment is required for it to work (Rivera, 2015). Furthermore, critics argues that, educators might resist its adoption on the basis of the need for the teacher to reevaluate teaching and instructional materials. Flipped classroom pedagogy demands more preparation time by both students and the instructor (Davis, 2016; Foster \& Stagl, 2018). 87\% of surveyed Hong Kong in-service secondary teachers reported that a flipped pedagogy is time ineffective considering that they were currently struggling with the face to face approach (Wang, 2017). 


\subsection{Class and online learning space}

It is imperative to note that active learning is taking center stage. In order to obtain desirable outcomes, the classroom environment should be equipped with necessary ingredients needed for peer instruction (Baepler, Walker, \& Driessen, 2014). Moveable desks should be put in a classroom installed with learning equipment like white boards, microphones, wireless internet, overhead projectors and speakers. Instructors ought to act like mentors in a group learning space and should give instant feedback as well as clarify misconceptions (Carter, Carter, \& Foss, 2018). Online lectures should be naturally shorter than live lectures because of the absence of side tracking and interruptions (Kerr, 2015).

\section{Methods}

\subsection{Searching and retrieval procedure}

In the period starting from September to October 2018, research articles were searched and downloaded from ScienceDirect, Taylor and Francis, Wiley, Springer, IEEE, Google Scholar, and Sage electronic databases. The following key words were used to obtain research-based articles from the mentioned databases; i.) Flipped classroom, ii.) Inverted classroom, and iii.) Peer instruction. Articles expressed in English were considered. Articles published in the period 2013 to 2018 were downloaded into a single file. The related references cited by the chosen articles were also considered and downloaded. Snowballing article searching technique was used to accumulate the articles. The cumulative number of publications in various searched electronic databases as at 21 October 2018 were as follows; ScienceDirect $(n=2459)$, Taylor and Francis $(n=5661)$, Wiley $(n=3703)$, Springer $(n=66)$, IEEE $(n=309)$, Sage $(n=2671)$ and Google Scholar $(n=56000)$.

\subsection{Filtering and sorting procedure}

The total number of articles retrieved and reviewed based on tittles, abstracts, methods and basic findings were 100. Articles extracts were tabulated under the following subheadings; i. Author and Year of publication, ii. Participants, iii. Context, iv. Study Design and Instruments, and v. Basic Findings. Non-TVET (Technology and Vocational Education and Training) related articles were deliberately excluded. The exclusion list was made up of 35 articles out of 100 retrieved articles. 


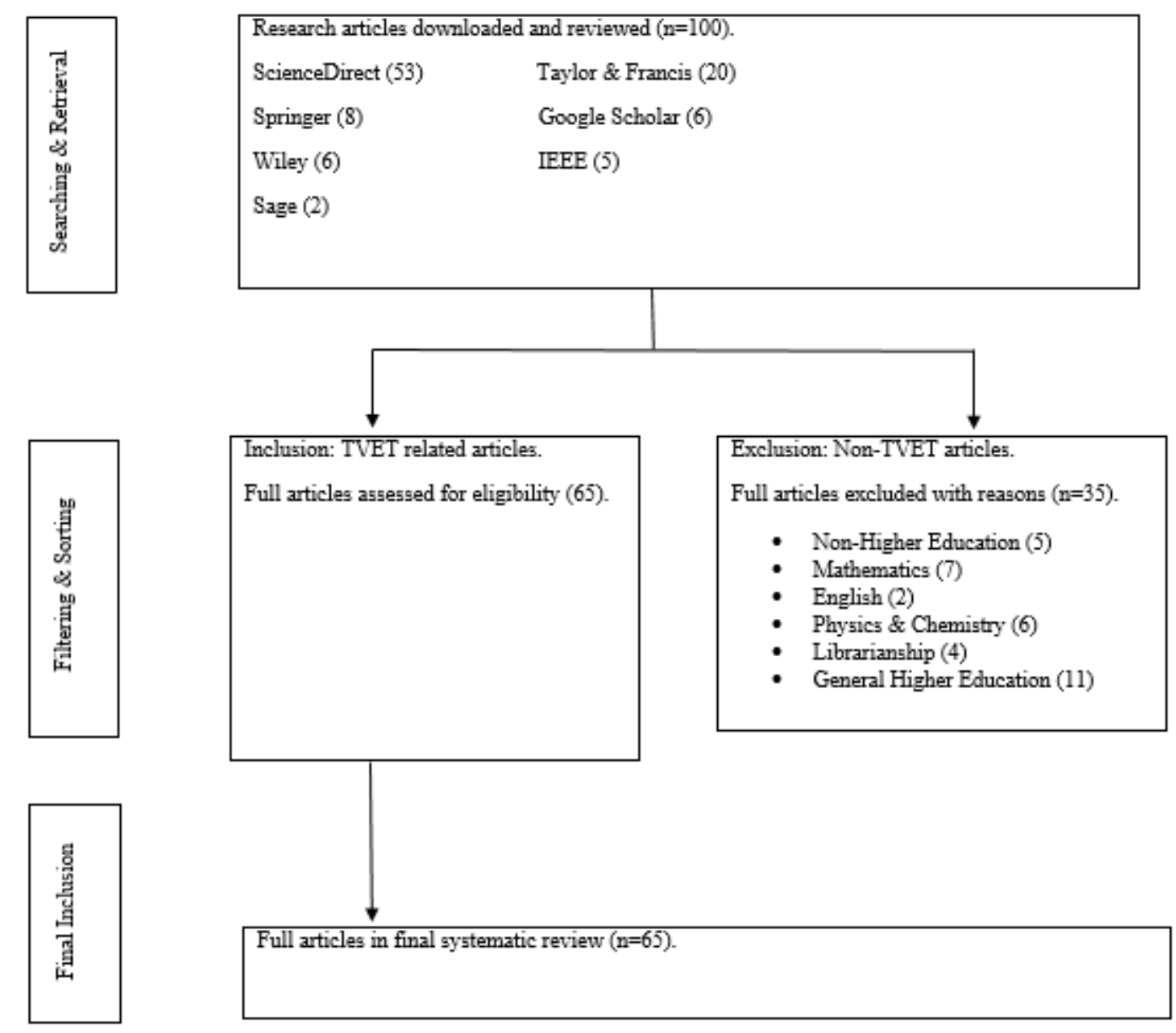

Figure 2. Flow diagram of systematic review process

\section{Results}

The majority of the articles focused on flipped learning pedagogy in relation to the following variables; 4.1 Students' Preference and Satisfaction, 4.2 Students' Performance, 4.3 Out-of-Class Preparations, 4.4 Students-Instructor Engagement, 4.5 Learning effort, Time and Pace, and 4.6 Cognitive Skills Formation.

\subsection{Students' preference and satisfaction}

Most students were impressed by the flipped classroom instructional pedagogy (Al-Zahrani, 2015; Ravishankar, Epps, \& Ambikairajah, 2018; Roach, 2014), although a limited number of students maintained their passive learning habits (Chen, Wang, \& Chen, 2014). In a case study comprising of 34 clinical pharmacy lecturers, $84 \%$ of the lecturers appreciated a flipped classroom pedagogy and $88 \%$ of the lecturers promised to adopt the model in their future classes (See \& Conry, 2014). Several other researchers also confirmed the same basic finding that a flipped class model is satisfying to both students and instructors than the traditional lecture-based model (Cotta et al., 2016; Chen, Wang, \& Chen, 2014; McNally et al., 2017; Michinov, Morice, \& Ferrières, 2015; Nikolic, Ros, \& Hastie, 2018; Saunders, Green, \& Cross, 2017; Street et al., 2015; Tan, Brainard, \& Larkin, 
2015; Wozny, Balser, \& Ives, 2018). For instance, in a survey consisting 120 tutees and 7 tutors, the tutees' average ratings were $6.97 \pm 1.93$ (from 1 =unsatisfactory to $10=$ excellent). Furthermore, in an action research involving 2 lecturers and varying number of students at each and every interval (2 or 3 or 4), flipped students were seen enjoying the active learning component of the flipped classroom model (Pappalepore \& Farrell, 2017). In a questionnaire survey by Hao (2016) with 84 undergraduates studying Information Technology and Education (79.1\% females and $20.9 \%$ males), $60 \%$ of the students reported that they preferred the flipped instructional pedagogy than the traditional lecture method.

In most questionnaire surveys, students were seen to prefer a flipped classroom model to the lecture-based model. For example, 92\% of group 1 and $100 \%$ of group 2 students liked flipped learning (Sohrabi \& Iraj, 2016), 95\% were satisfied and 37\% suggested that they would wish if flipped learning could be extended to all topics (Ravishankar, Epps, \& Ambikairajah, 2018), 90\% of engineering students endorsed the flipped model (Kakosimos, 2015; Munir et al., 2018). In a phenomenological study with 14 nursing students, kinesthetic learners were seen to be positive about flipped learning (Cramer's $V=0.849, P=0.006$ ), visual learners were negative (Cramer's $\mathrm{V}=0.701, \mathrm{p}=0.032$ ) while auditory learners were indifferent (Cramer's $\mathrm{V}=0.306, \mathrm{p}=0.52$ ) (Green \& Schlairet, 2017). Some unique students were also found to prefer some elements of the flipped classroom model. A questionnaire survey involving two courses (Professional Skills in Dietetics, $\mathrm{n}=148$ and Community Nutrition, $\mathrm{n}=48$ ) revealed that $70 \%, 64 \%$ and $70 \%$ of the students liked video lectures, active learning and student-teacher interaction respectively (Gilboy, Heinerichs, \& Pazzaglia, 2015). However, in Yilmaz (2017) study, satisfaction and motivation was found to be hinged on students' self-directed learning skills, internet self-efficacy, online communication selfefficacy, and computer self-efficacy.

Conversely, in some studies, students' reaction on the flipped classroom model was lukewarm and others felt that it was not ideal for students of certain backgrounds (Sohrabi \& Iraj, 2016). For example, in a two group quasi-experimental study with 343 lecture-based students and 334 flipped students, satisfaction levels were modest (flipped classroom; $m=3.631, \mathrm{SD}=1.538$ ) on a 6 point Likert scale (He et al., 2016). A descriptive and exploratory study involving nursing students studying Public Health Science and Population Health flipped courses (3rd year, $n=64$ and 2nd year, $n=93$ ) showed no significant differences in course evaluation with regards to flipped learning or traditional learning (Liebert et al., 2016).

Additionally, intriguing findings were found in an experimental study involving two mathematics courses in electrical engineering. Both mathematics course I and III had certain topics flipped. For mathematics course I, students' preference was seen decreasing over time, that is, in summer 2012 (51\%), winter 2012/13 (41\%), summer 2013 (23\%) while 67\% of course III students preferred flipped learning in 2012 (Braun, Ritter, \& Vasko, 2014). Opposing preferences were also noted in some studies. For instance, in a mixed method, crossover repeated measures study, nursing students learnt pharmacology as follows; both section $1(n=36)$ and section $2(n=40)$ learnt through 
convectional lecture method for 6 weeks and followed by 6 weeks of exclusive flipped learning by section 1. It was found that students were more satisfied by the traditional classroom approach than the flipped classroom approach (El-Banna, Whitlow, \& McNelis, 2017). An example of a student comment is; "I prefer topic experts leading discussions. Too many students bring nothing to the table" (Hanson, 2016). In addition, a small group (10-15\%) of flipped students were reported to prefer the traditional lecture-based method following 4 weeks and 6 weeks of being exposed to traditional lecture method and flipped classroom method respectively (Street et al., 2015). Flipped learning did not completely satisfy all learners in some instances. Quite a number of studies have shown flipped students resisting and hesitant when exposed to flipped learning for the first time although some students were seen gradually adjusting to the new learning set up with time (Elliott, 2015).

\subsection{Students' performance}

In some studies, flipped students slightly performed better than traditionally taught students (Beatty, Merchant, \& Albert, 2017; Caviglia-Harris, 2016; Fadol, Aldamen, \& Saadullah, 2018; He et al., 2016; Mason, Shuman, and Cook, 2013; O'Connor et al., 2016; Ravishankar, Epps, \& Ambikairajah, 2018; Street et al., 2015). For instance, flipped engineering students studying Dynamics of structures (Flipped class: $n=21$, Traditional class: $n=24$ ) obtained slightly higher test/quiz scores than students in traditional classes (Baytiyeh \& Naja, 2017).

A limited number of studies concluded that flipped students were significantly better in terms of grades than traditionally taught students (Olitsky \& Cosgrove, 2016). In a randomized experimental study, flipped ophthalmology clerkship students (Flipped class: $n=48$, Traditional class: $\mathrm{n}=47$ ) had significant high scores in the post-test (ocular trauma questions) $(16.91 \pm 1.67)$ than traditionally taught students $(14.92 \pm 1.01, p=0.01$, Effect size=1.44) (Tang et al., 2017). Using a quasi-experimental design, Calimeris (2018) investigated classes taught using convectional lecture method (fall 2012) and classes exposed to a flipped learning pedagogy (fall 2013 and fall 2014). Students in flipped classes obtained higher grades in the final exam. In a different study the adoption of a flipped classroom model also improved learning grades for both gifted and less gifted students (Lombardini, Lakkala, \& Muukkonen, 2018).

An interventional trial by Hsin-Yi Chiu et al. (2017) comprising 55 medical students who participated in a 1-hour laparoscopic skills training (Convectional class: $n=29$, Flipped class: $n=30$ ) revealed intriguing outcomes. Flipped students completed more stitches ( $m=0.47, \mathrm{SD}=0.507)$ than their traditional counterparts $(m=0.10, S D=0.310)$. Furthermore, flipped students also obtained higher stitch quality scores $(m=7.17, S D=2.73)$ than convectional students $(m=5.14, S D=1.767)$. Overall, flipped students had higher pass marks in the second $(p=0.001)$ and third $(p=0.002)$ sessions.

Rose et al. (2016) investigated the impact of a modified flipped classroom model. Residents studying Emergency medicine were grouped. Group A viewed videos uninterrupted while group B's video watching was interrupted with in between questions, 2-6 times per every 5-15 minutes interval. 
In 2015, group B residents who watched videos integrated with questions performed better than group A although the 2014 post-test results were similar. In a case study by Trpkovska and Bexheti (2017), (Traditional Class 2014: $n=36$, Flipped Class 2015: $n=49$, Flipped Class 2016: $n=22$ ), flipped students' scores were higher than the traditional students' scores, that is, $73 \%$ (2014), 90\% (2015) and 93\% (2016).

Conversely, other studies revealed opposing findings. For example, in a comparative study involving Team-Based Learning and flipped learning approaches, faculty referential exam results and students results confirmed Team-Based Learning approach as a better model than the flipped classroom model (Nishigawa et al., 2017). In addition, Taglieri et al. (2017) discovered that in terms of knowledge retention, traditionally taught students were better than the Flipped Team-based students $(62.9 \pm 19.3$ vs $54.9 \pm 15.53, p=0.001)$. Numerous studies also argued in favor of the traditional lecture-based method. For example, in a pro-convectional lecture-based method, it was found that instructor-led discussions increased students' performance more than peer discussions, $22 \%$ vs $14 \%$ (Zingaro \& Porter, 2014).

However, most studies reported an insignificant impact of a flipped classroom pedagogy on students' achievement. Using a quasi-experimental design, Kakosimos (2015) implemented the flipped classroom model to chemical engineering students (Course: Fluid Operations) in fall 2013 ( $n=18)$. In fall $2014(\mathrm{n}=20)$, the flipped classroom model was implemented in a Transport Process course which had $90 \%$ similar course materials. No significant changes were seen after the adoption of the flipped pedagogy in two successive years in similar different courses. Similarly, flipped classroom model was used to lecture 793 engineering students studying computer programming course. Students from various engineering disciplines constituted the class. The disciplines included; Computer $(n=26)$, Electrical $(n=112)$, Mechatronics $(n=77)$, Mechanical $(n=166)$, Materials $(n=20)$, Flexible $(n=70)$, Environmental $(n=28)$, Telecoms $(n=11)$, Civil $(n=260)$ and Mining $(n=23)$. Once again, there was no significant evidence to conclude that flipped learning improved discipline grades (Nikolic, Ros, \& Hastie, 2018).

Using a randomized experimental design, Harrington et al. (2015) assigned 82 baccalaureate students studying first level medical course into two groups (flipped cohort and traditional cohort). Authors found insignificant differences in outcomes between the traditional class and the flipped class in terms of course grades (traditional class: $M=86.4, S D=3.3$ vs flipped class: $M=86.2, S D=4.2$ ). Indifferences in exam scores were also reported by Braun, Ritter, and Vasko (2014).

Adding on, Cotta et al. (2016) surveyed students studying pharmaceutical calculation course. The 2011 cohort $(n=165)$ had section 1 exposed to the flipped classroom pedagogy and section 2 exposed to the traditional lecture-based pedagogy. All sections of the 2012 cohort $(n=151)$ exclusively learnt through the flipped classroom model. It was found that the 2012 cohort had better grades in section 2 materials (exam 2, $P=0.013$ ) and final exam part $B, P=0.001$ than 2011 cohort. That showed that in section 1 materials (exam 1) and final exam part $A$, no significant differences 
were realized. Several studies did not present convincing evidence on the impact of flipping the classroom on learners' performance (El-Banna, Whitlow, \& McNelis, 2017).

\subsection{Out-of-class preparations}

Numerous articles reported about the fundamental importance of preparing for active learning. Several researchers discovered that video viewing habits decelerated with the passage of time. For instance, Patanwala, Erstad, and Murphy (2017) found that $74 \%$ of the students adequately prepared for session 1,53\% prepared for session 2/ 3 and 36\% prepared for session 4. Additionally, Beatty, Merchant, and Albert (2017) noticed video views decreasing from a high of 700 views per video to between 100 and 300 views per video at the end of the semester. However, in some studies video views increased exponentially with the growing popularity of the flipped classroom model. For example, in a study in which flipped learning was implemented in 6 weeks in each of the academic years (2015 and 2017), 558 and 678 views were recorded respectively (Le Roux \& Nagel, 2018).

A notable video watching trend was also discovered. Most students watched videos when approaching exams. The study by Gulley and Jackson (2016) involving 81 video and 28 non-video students concluded that students were inclined to watch videos when preparing for exams. In that study, only $50 \%$ of the videos were fully watched. Patanwala, Erstad, and Murphy (2017) found that the median video view time was higher when students were required to complete a quiz than when there was no quiz [80 minutes (IQR: 38-114) versus 69 minutes (IQR: 3-105), p < 0.001]. Furthermore, a significant correlation between video view time (per $50 \%$ increment) and exam mark was established (coefficient 2.52; 95\% Cl: 0.79-4.26; $\mathrm{p}=0.005$; model R2=7.8\%).

Generally, most e-lectures were accessed, viewed and highly rated by the majority of the students outside class (Engel, Heinz, \& Sonntag, 2017; Le Roux \& Nagel, 2018). 48\% of best students and $34 \%$ of low performing students watched videos (Beatty, Merchant, \& Albert, 2017). Hanson (2016) found that 88\% $(n=23)$ in 2013 and 64\% $(n=16)$ in 2014 enjoyed watching and replaying e-lectures. 35\% (2013) and 32\% (2014) of the students watched $75 \%$ of the videos. The accompanying quizzes created a culture of studying e-lectures by students (Sohrabi \& Iraj, 2016). Students could have fell in love with video lectures because of their shortness (average time: 5-15 minutes). The video watching opportunities outside class enabled students to attend class with background knowledge (Fidalgo-Blanco et al., 2017).

However, in Hao (2016) study, 50\% of the students registered displeasure with video previews and the completion of quizzes outside class. Unprepared students were also found going through electures in class (AlJarrah, Thomas, \& Shehab, 2018). Students cited family, health, life, and work commitments, materials volumes and lack of time as major preparation obstacles (Hanson, 2016; Tan, Brainard, \& Larkin, 2015). Not surprisingly, a number of students were concerned with the inability to ask questions following video views (Gilboy, Heinerichs,\& Pazzaglia, 2015) and increased workload (Lombardini, Lakkala, \& Muukkonen, 2018). Students were also found failing to understand technical language presented in the learning videos (Green \& Schlairet, 2017) and struggled to 
adjust to a flipped classroom model at its launch (Mason, Shuman, and Cook, 2013), although some of the students gradually adjusted.

The flipped classroom model has potential to give desirable learning outcomes, if classroom practitioners and students prepare for active learning (Graham et al., 2017). In Long, Cummins, and Waugh (2017) study, instructors who attended the summer teaching institute training discovered the need to incentivize students to prepare and the need to timeously attend students' learning needs as critical. Instructors concurred that there was need to be well organized in terms of instructional goals and design.

\subsection{Student-instructor engagement}

Basically, flipped learning was found to promote students participation (Balaban, Gilleskie, \& Tran, 2016; Calimeris, 2018; Le Roux \& Nagel, 2018; Liebert et al., 2016; Morosan, Dawson, \& Whalen, 2017; Trpkovska \& Bexheti, 2017). Evaluation results for instructor effectiveness was rated above average $(m=3.26 \pm 0.94$ to $m=3.78 \pm 0.87)$ while group interaction was also rated above average $(m=3.41 \pm 0.98$ to $3.89 \pm 0.79)$ in a 5 -point Likert scale ( $1=$ Do not agree to $5=$ Completely agree) (Quoß, Rüttermann, \& Gerhardt-Szep, 2017). Instructor's presence encouraged higher levels of cognitive behavior (Blau \& Shamir-Inbal, 2017). Bring Your Own Device (BOYD) was also discovered to accelerate active learning before, during, and after attending class (Hao, 2016).

A dual case study (Case 1: Flipped part-time students, Case 2: Inverted Academic Seminar) revealed that an inverted classroom environment was conducive for clarity seeking, appealing, encouraged collaboration, increased student engagement, and was ideal for students with heterogeneous learning needs (Engel, Heinz, \& Sonntag, 2017). Social anxieties were eliminated within a cooperative flipped group compared to an individual flipped group (Eryilmaz \& Cigdemoglu, 2018). Hsu (2018) evaluated peer instruction aided by a smartphone application with two handles, time sequence-mode and like-ranking mode. The time sequence-mode $(n=36)$ was the experiment and the like-ranking mode was the control $(n=26)$. The findings revealed that the like-ranking mode accelerated the interaction between asking and answering questions, decreased quantities of useless messages, and refocused attention to questionable messages.

\subsection{Learning effort, time and pace}

The majority of the articles concurred that the flipped classroom model is time effective and maximizes learning outcomes (Gulley \& Jackson, 2016). Peer instruction eliminates the monotonous banking of knowledge experienced in an instructor-centered learning space. Most authors reported that the flipped classroom model allowed students to watch videos at own time, own pace, pause, rewind, fast forward videos as they please (Braun, Ritter, \& Vasko, 2014; Pappalepore \& Farrell, 2017; Roach, 2014). However flipped students were found to study longer before attending class [Effect size $(E S)=0.146, P=0.056$ ] and less time after class [ES $=-0152, p=0.047$ ] (He et al., 2016). Additionally, in the Brown, Danvers, and Doran (2016) study, reading questions completed outside 
class enhanced student knowledge on chapter materials and enabled them to spent more time on reading materials.

\subsection{Cognitive skills formation}

The majority of the articles concurred that a flipped classroom model was instrumental in the development Bloom's lower-order skills outside class and higher-order cognitive skills in the classroom (Hanson, 2016). Generally, most articles acknowledged that the flipped pedagogy enabled students to develop analytic, communication, problem solving, critical thinking, and creativity skills as well as fostering team work and self-regulation (Betihavas et al., 2016; Baytiyeh \& Naja, 2017; Morosan, Dawson, \& Whalen, 2017; Tang et al., 2017). Most students felt flipped learning was flexible, supportive, enabled heutagogy and active learning which fosters engagement (Simpson \& Richards, 2015).

\section{Discussion}

\subsection{Preparatory behaviors}

Students reacted differently to video viewing. Students in some empirical studies enjoyed video viewing. One possible explanation is that video lectures could have been short, interesting, interactive and precise or could have been considered the best alternative. Assuming learning independence could have overjoyed a significant number of learners. Popular reasons cited by literature includes video clarity, chronological presentation of concepts (Zainuddin \& Attaran, 2016), short and precise, 10 minutes (Fidalgo-Blanco et al., 2017), 10-20 minutes (Graham et al., 2017), and 5-15 minutes (He, Holton, \& Farkas, 2018). A significant correlation existed between video viewing and exam scores (Patanwala, Erstad, \& Murphy, 2017). This implies that long and uninteresting videos should be avoided at all costs as they can cause students to disengage with the learning materials. The accompanying quizzes and pending exams pushed students to prepare (Gulley \& Jackson, 2016). Although flipped learning fostered self-regulated learning, the use of unfamiliar language can turn off students' preparatory efforts (Green \& Schlairet, 2017).

On the contrary, taking lectures outside class in the form e-lectures produced unintended learning outcomes. For instance some students did not prepare before attending class (AlJarrah, Thomas, \& Shehab, 2018). In some studies, preparatory work was adversely affected by unplanned eventualities/exogeneous factors. Popular cited exogenous factors included family, life, health, and work commitments (Hanson, 2016; Tan, Brainard, \& Larkin, 2015). In some related studies, instructors resisted the flipped model because they considered it too demanding in terms of preparation, needed resources and required specialized IT support (Lee \& Lai, 2017). 


\subsection{Stakeholders feelings}

Overall, the review revealed overwhelming empirical evidence about how the flipped classroom model satisfies both instructors and students. Video lectures, Face to Face (F2F), and student-instructor interactivity were some of the ingredients that excited learners (Gilboy, Heinerichs, \& Pazzaglia, 2015). However, Yilmaz (2017) suggested that students' self-directed learning skills, internet self-efficacy, online communication self-efficacy, and computer self-efficacy were necessary determinants for student satisfaction and motivation in a flipped classroom. This might explain why students preferred the flipped classroom approach. Most students and instructors now possess these skills because of the ubiquitousness of information technology.

On the other hand, when surveyed on how satisfying and whether they prefer a flipped pedagogy, some students were lukewarm in their responses (Sohrabi \& Iraj, 2016). They could have shown indifferences because of some personal reasons. It could be that they were comfortable with all instructional pedagogies or just undecided. Additionally, some students who highly rated the flipped pedagogy at its launch subsequently developed a bad taste of it. This was shown by less video views with the progression of time (Braun, Ritter, \& Vasko, 2014). The nature of students could have influenced their attitude towards the flipped classroom model. For instance, some students openly resisted the model citing various reasons (Elliott, 2015). The resistance was also reflected by instructors as shown by literature. The major reasons for refusing it was its tendency to demand more preparation time.

\subsection{Students' interactivity, time effectiveness and cognitive skills formation}

Generally, most authors concluded that placing video lectures outside class enabled students to obtain lower-order cognitive skills before attending class (Hanson, 2016). During F2F interactions, students developed higher-order cognitive skills. High classroom participation was a sign that students engaged with the materials outside class. Students are less likely to engage with noninteractive learning materials (O'Flaherty \& Phillips, 2015). A number of studies concluded that a flipped pedagogy increases students participation (Morosan, Dawson, \& Whalen, 2017; Trpkovska \& Bexheti, 2017). Flipped classroom model is time effective in that homework is completed in class through peer instruction. Contrastingly, students were found to spent more time in self-directed learning (He et al., 2016). One possible reason could be increased video replays in an attempt to understand the learning materials.

\subsection{Performance}

No sufficient evidence was found on whether the flipped classroom model increased learning outcomes or not. Overall, most studies found that assessment scores were insignificantly higher in flipped classes than in traditional classes (Baytiyeh \& Naja, 2017; Beatty, Merchant, \& Albert, 2017; Ravishankar, Epps, \& Ambikairajah, 2018). Moreover, no significant changes were found between traditionally taught students and their flipped counterparts (Kakosimos, 2015; Nikolic, Ros, \& Hastie, 
2018). Conversely, in other studies, traditionally taught students significantly performed better than flipped students (Nishigawa et al., 2017; Taglieri et al., 2017; Zingaro \& Porter, 2014). One possible explanation is that flipped students had limited opportunities to ask questions as they interfaced with learning materials outside class.

A limited number of studies concluded that the flipped classroom model significantly improves academic performance (Tang et al., 2017; Lombardini, Lakkala, \& Muukkonen, 2018). A lot of factors such as learner caliber, resources quality and flipped classroom organization could have influenced the results.

\subsection{Fostering students' responsibility for their learning success}

Education is decisive for the development of the personality and the participation of the individual in the society. It is an indispensable condition for the ability of a modern and democratic society to face the future. The changes culminate in new demands on future concepts of learning and teaching. According to Wilsdorf, in this context not only the content of learning is important, but also the way it is learnt (Wilsdorf, 1991).

In this context, it becomes clear that the flipped classroom approach allows students to shoulder more responsibility for their own learning success. Thus the flipped classroom links up the over-arching goal of academic education, developing with a self-responsible personality, with the methodical approach in learning and teaching in academic institutions (Smith, 2008).

This conjunction is congruously, as ultimately it is an over-arching goal of academic education to promote the development of a self-responsible personalities. Yet, self-responsibility cannot be taught as such. Rather, it is about creating a framework in the educational process that enables the individual to develop into a self-responsible personality.

From this perspective too, flipped classroom is a valuable approach for the design of academic education processes.

\section{Conclusion}

The systematic review has identified few literature gaps. None of the empirical articles focused on real time delivery of instruction via online means like video conferencing. Secondly, no article dwelt on online real time F2F peer instruction. Future research should consider the possibility of taking both active learning and video e-lectures outside the classroom.

A big bang approach might be needed with regards to ensuring that everything needed is in place. Instructors should acquire IT skills needed to make learning materials. Instructor training institutions should also expose trainee instructors to the flipped classroom model during training. The mindsets of all classroom stakeholders should be prepared before implementing the flipped classroom pedagogy. The curriculum renewal processes should be inclusive. Training institutions should invest in relevant IT technologies that facilitates active and self-regulated learning. 
The article was intended to summarize empirical studies focusing on the flipped classroom model and identify research gaps that could inform future research trajectory. Previous empirical studies dwelt much on the impact of the flipped classroom pedagogy on students' opinions, academic performance, interactivity, outside class preparation, and flip budget. In this systematic review, technical and vocational related articles were considered. These included, technology, engineering, business, economics, medicinal and health related articles.

The flipped classroom model has great potential of improving learning grades in TVET related disciplines to a considerable extent. The flipped classroom model gives enough active learning space for the development of higher-order cognitive skills. Lower order thinking skills can be achieved through heutagogy outside the classroom. The majority of the articles concurred that a flipped classroom pedagogy was satisfying to both instructors and students although concerns on increased workload were raised. The flipped classroom model is cost effective for huge classes (O'Flaherty \& Phillips, 2015). The success of the flipped classroom model is hinged on good planning, implementation and evaluation (Long, Cummins, \& Waugh, 2017). Learning material should be properly prepared and tested before being used.

\section{References}

Abeysekera, L., and Dawson, P. (2015). Motivation and cognitive load in the flipped classroom: definition, rationale and a call for research. Higher Education Research and Development, 34(1), 1-14.

Al-Zahrani, A. M. (2015). From passive to active: The impact of the flipped classroom through social learning platforms on higher education students' creative thinking. British Journal of Educational Technology, 46(6), 1133-1148.

Albert, M., and Beatty, B. J. (2014). Flipping the Classroom Applications to Curriculum Redesign for an Introduction to Management Course: Impact on Grades. Journal of Education for Business, 89(8), 419-424.

AlJarrah, A., Thomas, M. K., and Shehab, M. (2018). Investigating temporal access in a flipped classroom: procrastination persists. International Journal of Educational Technology in Higher Education, 15(1), 1-18.

Arnold-Garza, S. (2014). The flipped classroom teaching model and its use for information literacy instruction. Communications in Information Literacy, 8(1), 7-22.

Baepler, P., Walker, J. D., and Driessen, M. (2014). It's not about seat time: Blending, flipping, and efficiency in active learning classrooms. Computers and Education, 78, 227-236.

Balaban, R. A., Gilleskie, D. B., and Tran, U. (2016). A quantitative evaluation of the flipped classroom in a large lecture principles of economics course. Journal of Economic Education, 47(4), 269-287.

Baytiyeh, H., and Naja, M. K. (2017). Students' perceptions of the flipped classroom model in an engineering course: a case study. European Journal of Engineering Education, 42(6), 1048-1061. 
Beatty, B. J., Merchant, Z., and Albert, M. (2017). Analysis of Student Use of Video in a Flipped Classroom. TechTrends, 1-10.

Becker, R., and Birdi, A. (2018). Flipping the classroom: Old ideas, new technologies. International Review of Economics Education, 1-5.

Bergmann, J., and Sams, A. (2012). Flipping your classroom: Reach every student in every class every day. International society for technology in education.

Betihavas, V., Bridgman, H., Kornhaber, R., and Cross, M. (2016). The evidence for "flipping out": A systematic review of the flipped classroom in nursing education. Nurse Education Today, 38, 15-21.

Blau, I., and Shamir-Inbal, T. (2017). Re-designed flipped learning model in an academic course: The role of co-creation and co-regulation. Computers \& Education, 115, 69-81.

Braun, I., Ritter, S., and Vasko, M. (2014). Inverted Classroom by Topic - a Study in Mathematics for Electrical Engineering Students. International Journal of Engineering Pedagogy, 4(3), $11-17$.

Brown, C. A., Danvers, K., and Doran, D. T. (2016). Student perceptions on using guided reading questions to motivate student reading in the flipped classroom. Accounting Education, 25(3), 256-271.

Calimeris, L. (2018). Effects of flipping the principles of microeconomics class: Does scheduling matter? International Review of Economics Education, 29, 29-43.

Calimeris, L., and Sauer, K. M. (2015). Flipping out about the flip: All hype or is there hope? International Review of Economics Education, 20, 13-28.

Carter, C. L., Carter, R. L., and Foss, A. H. (2018). The Flipped Classroom in a Terminal College Mathematics Course for Liberal Arts Students. AERA Open, 4(1), 233285841875926.

Caviglia-Harris, J. (2016). Flipping the undergraduate economics classroom: Using online videos to enhance teaching and learning. Southern Economic Journal, 83(1), 321-331

Chen, Y., Wang, Y., and Chen, N. S. (2014). Is FLIP enough? Or should we use the FLIPPED model instead?. Computers \& Education, 79, 16-27.

Chiu, H. Y., Kang, Y. N., Wang, W. L., Huang, H. C., Wu, C. C., Hsu, W., ... and Wei, P. L. (2018). The Effectiveness of a Simulation-Based Flipped Classroom in the Acquisition of Laparoscopic Suturing Skills in Medical Students-A Pilot Study. Journal of surgical education, 75(2), 326-332.

Cotta, K. I., Shah, S., Almgren, M. M., Macías-Moriarity, L. Z., and Mody, V. (2016). Effectiveness of flipped classroom instructional model in teaching pharmaceutical calculations. Currents in Pharmacy Teaching and Learning, 8(5), 646-653.

Davis, N. L. (2016). Anatomy of a flipped classroom. Journal of Teaching in Travel and Tourism, 16(3), 228-232.

El-Banna, M. M., Whitlow, M., and McNelis, A. M. (2017). Flipping around the classroom: Accelerated Bachelor of Science in Nursing students' satisfaction and achievement. Nurse Education Today, 56, 41-46. 
Elliott, R. (2015). Do students like the flipped classroom? An investigation of student reaction to a flipped undergraduate IT course. Proceedings - Frontiers in Education Conference, FIE (pp. 1-7).

Engel, M., Heinz, M., and Sonntag, R. (2017). Flexibilizing and Customizing Education using Inverted Classroom Model. Information Systems Management, 34(4), 378-389.

Eryilmaz, M., and Cigdemoglu, C. (2018). Individual flipped learning and cooperative flipped learning: their effects on students' performance, social, and computer anxiety. Interactive Learning Environments, 0(0), 1-11.

Fadol, Y., Aldamen, H., and Saadullah, S. (2018). A comparative analysis of flipped, online and traditional teaching: A case of female Middle Eastern management students. International Journal of Management Education, 16(2), 266-280.

Ferreri, S. P., and O'Connor, S. K. (2013). Redesign of a large lecture course into a small-group learning course. American journal of pharmaceutical education, 77(1), 13.

Fidalgo-Blanco, A., Martinez-Nuñez, M., Borrás-Gene, O., and Sanchez-Medina, J. J. (2017). Micro flip teaching-An innovative model to promote the active involvement of students. Computers in Human Behavior, 72, 713-723.

Foster, G., and Stagl, S. (2018). Design, implementation, and evaluation of an inverted (flipped) classroom model economics for sustainable education course. Journal of Cleaner Production, 183, 1323-1336.

Gilboy, M. B., Heinerichs, S., and Pazzaglia, G. (2015). Enhancing student engagement using the flipped classroom. Journal of Nutrition Education and Behavior, 47(1), 109-114.

Graham, M., McLean, J., Read, A., Suchet-Pearson, S., and Viner, V. (2017). Flipping and still learning: experiences of a flipped classroom approach for a third-year undergraduate human geography course. Journal of Geography in Higher Education, 41(3), 403-417.

Green, R. D., and Schlairet, M. C. (2017). Moving toward heutagogical learning: Illuminating undergraduate nursing students' experiences in a flipped classroom. Nurse Education Today, 49, 122-128.

Guerrero, S., Beal, M., Lamb, C., Sonderegger, D., and Baumgartel, D. (2015). Flipping undergraduate finite mathematics: Findings and implications. Primus, 25(9-10), 814-832.

Gulley, O. D., and Jackson, A. L. (2016). A case study on using instructor-recorded videos in an upper level economics course. International Review of Economics Education, 23, 28-33.

Hanson, J. (2016). Surveying the experiences and perceptions of undergraduate nursing students of a flipped classroom approach to increase understanding of drug science and its application to clinical practice. Nurse Education in Practice, 16(1), 79-85.

Hao, Y. (2016). Exploring undergraduates' perspectives and flipped learning readiness in their flipped classrooms. Computers in Human Behavior, 59, 82-92.

Harrington, S. A., Bosch, M. V., Schoofs, N., Beel-Bates, C., and Anderson, K. (2015). Quantitative outcomes for nursing students in a flipped classroom. Nursing Education Perspectives, 36(3), 179-181.

He, W., Holton, A., Farkas, G., and Warschauer, M. (2016). The effects of flipped instruction on outof-class study time, exam performance, and student perceptions. Learning and Instruction, $45,61-71$. 
He, W., Holton, A. J., and Farkas, G. (2018). Impact of partially flipped instruction on immediate and subsequent course performance in a large undergraduate chemistry course. Computers and Education, 125, 120-131.

Hsu, T. C. (2018). Behavioural sequential analysis of using an instant response application to enhance peer interactions in a flipped classroom. Interactive Learning Environments, 26(1), 91-105.

Kakosimos, K. E. (2015). Example of a micro-adaptive instruction methodology for the improvement of flipped-classrooms and adaptive-learning based on advanced blended-learning tools. Education for Chemical Engineers, 12, 1-11.

Kerr, B. (2015). The flipped classroom in engineering education: A survey of the research. 2015 International Conference on Interactive Collaborative Learning (ICL), (pp. 815-818).

Kim, M. K., Kim, S. M., Khera, O., and Getman, J. (2014). The experience of three flipped classrooms in an urban university: an exploration of design principles. The Internet and Higher Education, 22, 37-50.

Kong, S. C., and Song, Y. (2015). An experience of personalized learning hub initiative embedding BYOD for reflective engagement in higher education. Computers and Education, 88, 227240.

Kurbanoĝlu, S., and Akkoyunlu, B. (2016). Information Literacy and Flipped Learning. Pathways into Information Literacy and Communities of Practice: Teaching Approaches and Case Studies (pp. 53-84). Elsevier.

Le Roux, I., and Nagel, L. (2018). Seeking the best blend for deep learning in a flipped classroomviewing student perceptions through the Community of Inquiry lens. International Journal of Educational Technology in Higher Education, 15(1), 16.

Lee, K., and Lai, Y. (2017). Facilitating higher-order thinking with the flipped classroom model: a student teacher's experience in a Hong Kong secondary school. Research and Practice in Technology Enhanced Learning, 12(1), 8.

Liebert, C. A., Mazer, L., Merrell, S. B., Lin, D. T., and Lau, J. N. (2016). Student perceptions of a simulation-based flipped classroom for the surgery clerkship: A mixed-methods study. Surgery, 160(3), 591-598.

Lombardini, C., Lakkala, M., and Muukkonen, H. (2018). The impact of the flipped classroom in a principles of microeconomics course: evidence from a quasi-experiment with two flipped classroom designs. International Review of Economics Education, 29, 14-28.

Long, T., Cummins, J., and Waugh, M. (2017). Use of the flipped classroom instructional model in higher education: instructors' perspectives. Journal of Computing in Higher Education, 29(2), 179-200.

Lopes, A. P., and Soares, F. (2018). Perception and performance in a flipped Financial Mathematics classroom. International Journal of Management Education, 16(1), 105-113.

Mason, G. S., Shuman, T. R., and Cook, K. E. (2013). Comparing the effectiveness of an inverted classroom to a traditional classroom in an upper-division engineering course. IEEE Transactions on Education, 56(4), 430-435.

McNally, B., Chipperfield, J., Dorsett, P., Del Fabbro, L., Frommolt, V., Goetz, S., ... and Roiko, A. (2017). Flipped classroom experiences: student preferences and flip strategy in a higher education context. Higher Education, 73(2), 281-298. 
Michinov, N., Morice, J., and Ferrières, V. (2015). A step further in Peer Instruction: Using the Stepladder technique to improve learning. Computers and Education, 91, 1-13.

Morosan, C., Dawson, M., and Whalen, E. A. (2017). Using Active Learning Activities to Increase Student Outcomes in an Information Technology Course. Journal of Hospitality and Tourism Education, 29(4), 147-157.

Munir, M. T., Baroutian, S., Young, B. R., and Carter, S. (2018). Flipped classroom with cooperative learning as a cornerstone. Education for Chemical Engineers, 23, 25-33.

Murphy, J., Chang, J. M., and Suaray, K. (2016). Student performance and attitudes in a collaborative and flipped linear algebra course. International Journal of Mathematical Education in Science and Technology, 47(5), 653-673.

Nikolic, S., Ros, M., and Hastie, D. B. (2018). Teaching programming in common first year engineering: discipline insights applying a flipped learning problem-solving approach. Australasian Journal of Engineering Education, 00(00), 1-12.

Nishigawa, K., Omoto, K., Hayama, R., Okura, K., Tajima, T., Suzuki, Y., ... and Matsuka, Y. (2017). Comparison between flipped classroom and team-based learning in fixed prosthodontic education. Journal of prosthodontic research, 61(2), 217-222.

O'Connor, E. E., Fried, J., McNulty, N., Shah, P., Hogg, J. P., Lewis, P., ... and Reddy, S. (2016). Flipping radiology education right side up. Academic radiology, 23(7), 810-822.

O'Flaherty, J., and Phillips, C. (2015). The use of flipped classrooms in higher education: A scoping review. Internet and Higher Education, 25, 85-95.

Olitsky, N. H., and Cosgrove, S. B. (2016). The better blend? Flipping the principles of microeconomics classroom. International Review of Economics Education, 21, 1-11.

Pappalepore, I., and Farrell, H. (2017). Redressing the balance: Inverted hierarchies in the tourism classroom. Journal of Hospitality, Leisure, Sport and Tourism Education, 21, 144-153.

Patanwala, A. E., Erstad, B. L., and Murphy, J. E. (2017). Student use of flipped classroom videos in a therapeutics course. Currents in Pharmacy Teaching and Learning, 9(1), 50-54.

Quoß, M., Rüttermann, S., and Gerhardt-Szep, S. (2017). Cross-year-Peer-Assisted Learning im Inverted-Classroom-Szenario: Pilotprojekt aus der Zahnmedizin. Zeitschrift fur Evidenz, Fortbildung und Qualitat im Gesundheitswesen, 126, 84-93.

Ravishankar, J., Epps, J., and Ambikairajah, E. (2018). A flipped mode teaching approach for large and advanced electrical engineering courses. European Journal of Engineering Education, 43(3), 413-426.

Rivera, E. (2015). Using the Flipped Classroom Model in Your Library Instruction Course. Reference Librarian, 56(1), 34-41.

Roach, T. (2014). Student perceptions toward flipped learning: New methods to increase interaction and active learning in economics. International Review of Economics Education, 17, 7484.

Roehl, A., Reddy, S. L., and Shannon, G. J. (2013). The flipped classroom: An opportunity to engage millennial students through active learning strategies. Journal of Family and Consumer Sciences, 105(2), 44-49. 
Rose, E., Claudius, I., Tabatabai, R., Kearl, L., Behar, S., and Jhun, P. (2016). The flipped classroom in emergency medicine using online videos with interpolated questions. The Journal of emergency medicine, 51(3), 284-291.

Saunders, A., Green, R., and Cross, M. (2017). Making the most of person-centred education by integrating flipped and simulated teaching: An exploratory study. Nurse Education in Practice, 27, 71-77.

See, S., and Conry, J. M. (2014). Flip My Class! A faculty development demonstration of a flippedclassroom. Currents in Pharmacy Teaching and Learning, 6(4), 585-588.

Şengel, E. (2016). To FLIP or not to FLIP: Comparative case study in higher education in Turkey. Computers in Human Behavior, 64, 547-555.

Simpson, V., and Richards, E. (2015). Flipping the classroom to teach population health: Increasing the relevance. Nurse Education in Practice, 15(3), 162-167.

Smith, R. (2008). Learner autonomy. ELT journal, 62(4), 395-397.

Sohrabi, B., and Iraj, H. (2016). Implementing flipped classroom using digital media: A comparison of two demographically different groups' perceptions. Computers in Human Behavior, 60, 514-524.

Street, S. E., Gilliland, K. O., McNeil, C., and Royal, K. (2015). The flipped classroom improved medical student performance and satisfaction in a pre-clinical physiology course. Medical Science Educator, 25(1), 35-43.

Taglieri, C., Schnee, D., Camiel, L. D., Zaiken, K., Mistry, A., Nigro, S., ... and Goldman, J. (2017). Comparison of long-term knowledge retention in lecture-based versus flipped team-based learning course delivery. Currents in Pharmacy Teaching and Learning, 9(3), 391-397.

Tan, E., Brainard, A., and Larkin, G. L. (2015). Acceptability of the flipped classroom approach for in-house teaching in emergency medicine. EMA - Emergency Medicine Australasia, 27(5), 453-459.

Tang, F., Chen, C., Zhu, Y., Zuo, C., Zhong, Y., Wang, N., ... and Liang, D. (2017). Comparison between flipped classroom and lecture-based classroom in ophthalmology clerkship. Medical education online, 22(1), 1395679.

Trpkovska, M. A., and Bexheti, L. A. (2017). Enhancing flipped classroom model implementation. 2017 6th Mediterranean Conference on Embedded Computing (MECO) (pp. 1-4). IEEE.

Wang, T. (2017). Overcoming barriers to "flip": building teacher's capacity for the adoption of flipped classroom in Hong Kong secondary schools. Research and Practice in Technology Enhanced Learning, 12(1), 6.

Wilsdorf, D. (1991). Schlüsselqualifikationen: die Entwicklung selbständigen Lernens und Handelns in der industriellen gewerblichen Berufsausbildung. München: Lexika Verlag.

Wozny, N., Balser, C., and Ives, D. (2018). Evaluating the flipped classroom: A randomized controlled trial. Journal of Economic Education, 49(2), 115-129.

Yilmaz, R. (2017). Exploring the role of e-learning readiness on student satisfaction and motivation in flipped classroom. Computers in Human Behavior, 70, 251-260.

Zainuddin, Z., and Attaran, M. (2016). Malaysian students' perceptions of flipped classroom: a case study. Innovations in Education and Teaching International, 53(6), 660-670. 
invotec XVI:1 (2020) 11-31

Zingaro, D., and Porter, L. (2014). Peer Instruction in computing: The value of instructor intervention. Computers and Education, 71, 87-96. 